\title{
Raising the Dead: Rediscovery and redescription of some lost spider types (Araneae) described by Eugène Simon
}

\author{
Nadine Dupérré ${ }^{1}$, Danilo Harms ${ }^{1}$ \\ 1 Department of Arachnology, Centrum für Naturkunde, Universität Hamburg, Germany \\ http://zoobank.org/959216D5-79ED-477F-B636-4BB712BBFA24 \\ Corresponding author: Nadine Dupérré (nadine.duperre@uni-hamburg.de)
}

Received 31 January 2018

Accepted 8 March 2018

Published 19 March 2018

Academic editor:

Martin Husemann

\section{Key Words}

\section{Dictynidae}

Linyphiidae

Lycosidae

nomen dubium

type catalogue

Wilhelm Michaelsen

\begin{abstract}
In this paper, we are redescribing type material from the Zoological Museum in Hamburg that was thought to be lost. These specimens were described in 1902 by Eugène Simon from material collected in Southern Patagonia and Fireland but the species were subsequently considered nomina dubia, or simply not considered at all. The rediscovery of this material leads to the revalidation of two genera and four species. The genera Clitistes and Zilephus are reinstated and the species Clitistes velutinus Simon, 1902 (Dictynidae), Zilephus granulosus Simon, 1902, Minyriolus australis Simon, 1902 (both Linyphiidae), and Lycosa michaelseni Simon, 1902 (Lycosidae) are redescribed. To avoid further confusion, we designate lectotypes for: Linyphiidae: Minyriolus australis Simon, 1902, Gongylidiellum uschuaiense Simon, 1902, Neriene fuegiana Simon, 1902, Clitistes velutinus Simon, 1902, Zilephus granulosus Simon, 1902; Amphinectidae: Rubrius radulifer Simon, 1902; Hahniidae: Hahnia michaelseni Simon, 1902, Bigois antarctica Simon, 1902 and Lycosidae: Lycosa michaelseni Simon, 1902. For all prior nomina dubia and newly designated lectotypes, the type specimens are re-described and properly illustrated for the first time.
\end{abstract}

\section{Introduction}

Eugène Simon (1848-1924) is considered by many arachnologists as the prime father of systematic spider research and still widely praised as the most prolific spider taxonomist of all times. Simon worked at the Muséum national d'Histoire Naturelle in Paris where most of his type specimens are deposited. Determination of type material by subsequent researchers has often been problematic, mainly because Simon did not declare type material in his original descriptions. Simon also described material from other collections but rarely stated the type depository, which was common practice back then but is an essential element of taxonomic descriptions today. Simon is not to be blamed for his approach because taxonomic standards were very different back then. It is perhaps surprising that type material described by Eugène Simon was recently rediscovered at the Zoological Museum in Hamburg (ZMH); a collection that is renowned for its mite and scorpion types, but also essential col- lections of Australian and European spiders described by famous arachnologists such Eugen von Keyserling and Ludwig Carl Christian Koch. An inventory of the spider collection at the ZMH recently revealed the presence of additional spider material described by Simon that has long been forgotten. In 1902, Simon published a paper reporting on 77 arachnid species excluding Acari and Gongyleptid from "Tierra del Fuego". Except for three species (Tryssothele latastei, Rubrius livens and Echemus argutus) all other species/specimens were collected by Prof. J. Wilhem Michaelsen in an expedition to Southern Patagonia and Fireland and deposited at the Zoological Museum in Hamburg.

\section{The Hamburger Magalhaensische Sammelreise 1892/1893}

In 1890, a commission was set up to plan an expedition to Southern Patagonia and Fireland, but the expedition 
was delayed due to political instability in Chile. Wilhelm Michaelsen left Hamburg in late July 1892 and returned to Hamburg on the $10^{\text {th }}$ September 1893 with great success (Neumayer 1896). Michaelsen left the port of Hamburg on July 23 and reached Punta Arenas on the $29^{\text {th }}$ August 1892. Unlike some other expeditions at that time, he wrote an extensive travel report that was published in the first volume of the "Ergebnisse der Hamburger Magalhaensischen Sammelreise 1892" (Michaelsen 1896) and provided concise details of his expedition from Punta Arenas to Uschuaia, to Puerto Toro, Lennox, Cap San Pio, Puerto Pantalon, Puerto Bridges, Valvidia and finally Chamilchamil. The main objective of the expedition was to collect specimens from the low seas, but nonetheless Michaelsen managed to collect numerous terrestrial animals as well. Michaelsen's travel report provides valuable historical, geographical and biological information that supplement to the basic locality data found on the labels. Wilhem Michaelsen was the curator of the invertebrate department of the Hamburg Museum between 1887-1923 and primarily interested in oligochaete worms, but also led three major expeditions to south-western America, South Africa and south-western Australia to investigate faunal similarities caused by continental drift, which was an emerging theory at that time. The results of the expedition were published in three major volumes between 1896-1907, with the second volume focusing on arthropods and including the paper on arachnids by Eugène Simon, but also contributions on harvestmen by William Sørensen and mites by Paul Kramer.

\section{The arachnid specimens described by Simon}

After the return of the expedition, the arachnid specimens were integrated into the invertebrate collections of the Zoological Museum in Hamburg and forwarded to the taxonomic authorities for identification and description. It was the then-director of the museum Karl Kraepelin who invited Eugène Simon to participate in the analysis of the the specimens collected of the expedition. Eugène Simon was already a well-established arachnologist and had published on arachnids from Patagonia, Cape Horn and Terrede-Feu (Simon 1886, 1887, 1889, 1895, 1896). In his 1902 paper, he wrote, "I gladly accepted to deal with the arachnoids collected with great care by Dr. Michaelsen". In this paper, Simon reported on a total of 77 species (the three species that were not collected by Michaelsen are not included in the numbering list and are from an unknown collection): from which he described two new genera, 29 new species of spiders, one new species of pseudoscorpion and one new species of harvestmen. All the type material mentioned in the paper was found at the $\mathrm{ZMH}$, except for two species (see discussion), furthermore almost all the specimens of the none-type material reported and collected by Michaelsen are present in the ZMH collection.

Unfortunately, Simon did not mention the number of specimens he examined and refrained from illustrating the specimens. Consequently, it has been somewhat difficult for subsequent arachnologists to recognise the species but also to determine their status (holotype or lectotypes).

The present paper re-analyses part of the spider material presented by Simon in 1902; only the species that were designated as nomina dubia or species with problematic holotype designation are re-analysed. The present paper aims to i) re-establish "lost" genera and species that were wrongly declared to be invalid or nomina dubia; ii) designate lectotypes from the syntype series; and iii) illustrate and describe in necessary details the newly designated lectotypes.

\section{Material and methods}

\section{Specimen storage and curation}

All specimens are deposited at the Zoological Museum $(\mathrm{ZMH})$, Centrum für Naturkunde, at the University of Hamburg. Specimens are stored in jars with $75 \% \mathrm{EtOH}$ but kept in separate vials inside the jars to avoid damage from the labels, dissected parts are kept in microvials.

\section{Terminology and lab methods}

The taxonomy follows the World Spider Catalogue (2018). The definition of holotype, syntype, neotype and lectotype follows the International Code for Zoological Nomenclature (ICZN 2017). Articles 73-74 were applied when determining holotype status and designation of lectotypes and paralectotypes. The following criteria were considered: i) the lectotype matches the size and illustrations presented originally; and ii) the lectotype was chosen from syntypes from the collection with the largest number of syntypes, or from the collection upon which the author of the species worked, or containing the majority of that author's types. For newly designated lectotypes, complete locality, size, sex, condition of the specimens, together with a detailed description and illustrations are given. We also follow ICZN recommendation $73 \mathrm{~F}$ and designate lectotypes for the nominal species-group taxa rather than assuming a holotype because additional syntypes may exist (ICZN 2017). The code also recommends (recommendation $74 \mathrm{G}$ ) that lectotye designation should not be done for curatorial purpose only, but as part of revisionary work or other taxonomic work. The paper present for all lectotype designations, a complete taxonomic description with photos and illustrations of the important taxonomic characters as well as taxonomical changes. Cardfiles of the Muséum national d'Histoire Naturelle in Paris (MNHN) were not examined; they may have valuable information, but they would not help determined the status of a type, as they were written later on. For every species, the original publication as well as the original spelling of the species name is provided. The primary data (type locality, name of the collector, year of collection, number and sex of specimens, type status of specimens) and body measurements are given in the original wording and language. The data from the labels 


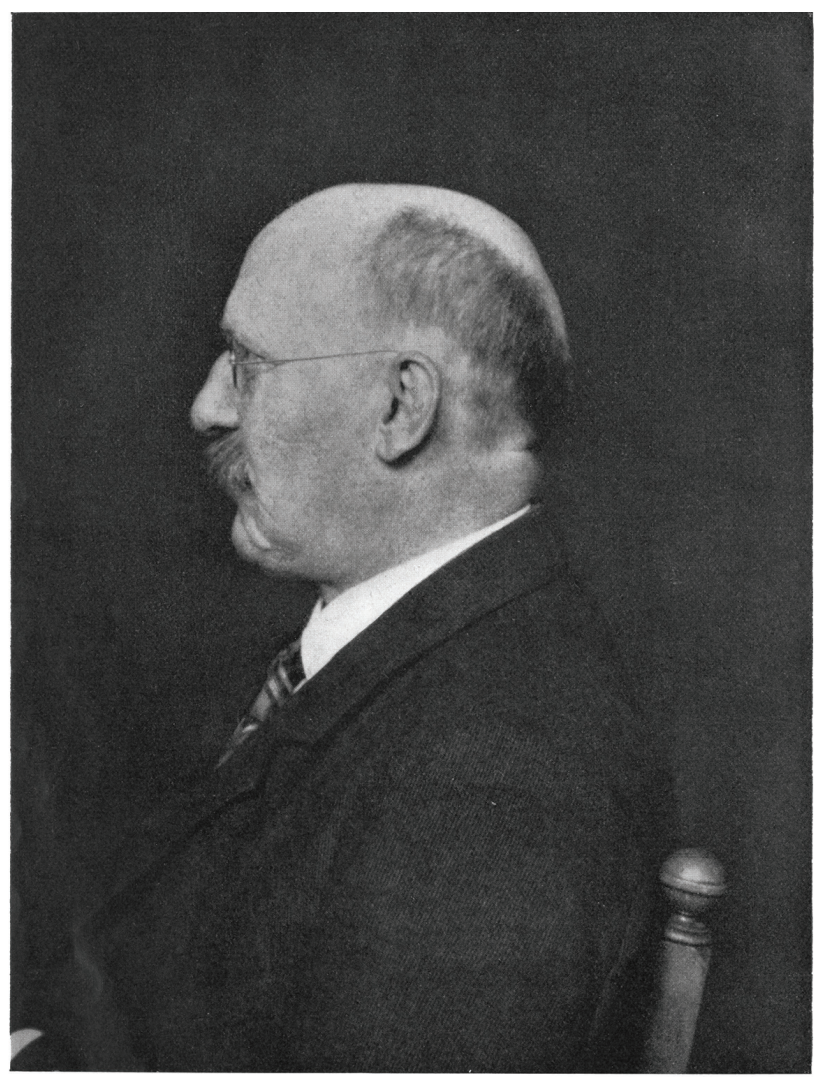

A
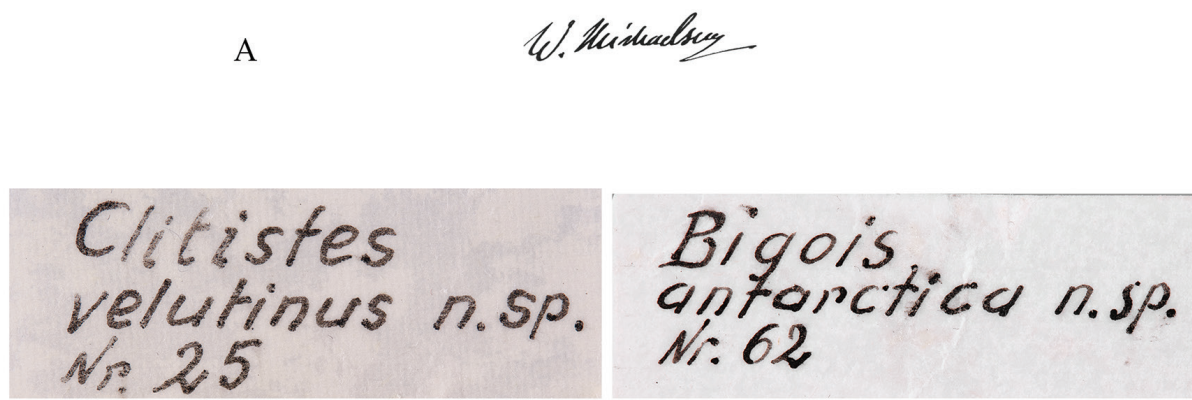

B
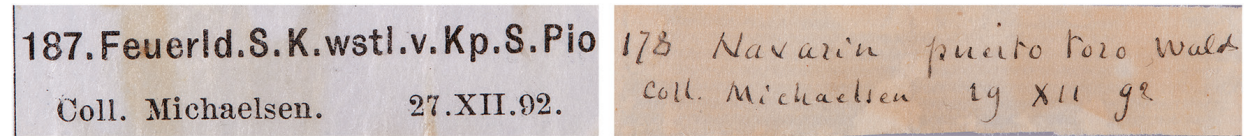

$\mathrm{C}$

Figure 1. A. Photo of Prof. J. Wilhem Michaelsen. B. Examples of labels with Eugène Simon numbering system. C. Examples of locality labels.

(determination and locality labels) are given in their original wording. The manuscript is presented in the same order as Simon paper published his descriptions in 1902. Imaging of the specimens was done with a BK Plus Lab System by Dun, Inc. (see Harms and Dupérré 2018). All measurements are in millimeters and were made using a micrometric ruler fitted on the eyepiece of a Leica M125 stereomicroscope. The coloration description is given based on the original description (translated into English), because the specimens are now discoloured and pale. The height of the clypeus is calculated in relation to the size of the anterior median eyes, as mentioned in the description. Measurement for the position of trichobothria of metatarsi I follows Denis (1949). Abbreviations: Somatic Morphology: ALE: anterior lateral eyes; AME: anterior median eyes; PLE: posterior lateral eyes; PME: posterior median eyes; Tm I: trichobothria of metatarsi I. Genitalia (female): ap: anterior pocket; cd: copulatory ducts; co: copulatory openings; ms: median septum; s: spermathecae. Genitalia (male): e: embolus; c: conductor; ma: median apophysis; pp: patellar process; t: tegulum; ta: terminal apophysis; tbp: tibial basal process; tp: tibial process. 


\section{Taxonomy}

\section{Family Linyphiidae Blackwall, 1859 \\ Minyriolus Simon, 1884}

\section{Minyriolus australis Simon, 1902}

Fig. 2A-C

Minyriolus australis Simon, 1902: 15 (as Minyriolus (?) australis n. sp., description female)

Type locality. Coll. Mich. 130. Süd-Feuerland, Uschuaia, Süßwassersee auf der Halbinsel, 19.XII.92.

Dimensions. + . long. $1 \mathrm{~mm}$.

Determination label. Minyriolus (?) australis n.sp., Nr. 16.

Locality label. 130. Uschuaia; Süsswasser-See auf d. Halbinsel. Coll. Michaelsen. 19.XI.92.

Remarks. In 2007, Miller declared this species a nomen dubium: "The otherwise Palearctic genus Minyriolus was represented in the Neotropics by M. australis Simon 1902; specimens of $M$. australis could not be located and it is considered nomen dubium". The specimen deposited in the Hamburg collection is indisputably part of the type series.

Type material. Lectotype $q$ designated here (ZMH-A0000756). Abdomen detached from body.

Type material. Female (lectotype). Total length: 1.23; cephalothorax length 0.55 ; cephalothorax width: 0.38 . COLORATION: (based on original description, translated from Latin): "cephalothorax bright olive-brown with thin black margin, ocular area blackish. Sternum black. Abdomen light brown. Legs pale yellow-reddish". CEPHALOTHORAX: Longer than wide (Fig. 2A), pars cephalica sinuous, pars thoracica slooping gradually; clypeus 2xAME; sternum as long as wide. EYES: round, all surround by black pigment; AME smallest, AME touching, AME-LE touching, LE touching, LE-PME slightly separated, PME separated by their radius. LEG: Tm I: 0.61.

ABDOMEN: Oval (Fig. 2A). GENITALIA: Epigynum slightly protruding basally; two large, rounded spermathecae visible through integument (Figs 2B, C).

Male. Unknown.

Distribution. Argentina: Uschuaia.

Taxonomic note. The genus Minyriolus is composed of three Palearctic species (World Spider Catalogue 2018). Even though its is unlikely that this species belongs to this genus (as already indicated by Simon in the original publication, the generic name is written with a "?"), we argue that is should be left in this genus, pending taxonomic revision.

Current systematic position. Linyphiidae, Minyriolus australis Simon, 1902.

\section{Gongylidiellum uschuaiense Simon, 1902}

Fig. 3A-C

Gongylidiellum uschuaiense Simon, 1902: 16. (as Gongylidiellum (?) uschuaiense n. sp., description female).
Type locality. Coll. Mich. 142. Süd-Feuerland, Uschuaia; 14.XII.92.

Dimensions. + . long. $0,8 \mathrm{~mm}$.

Determination label. Gongylidiellum (?) uschuaiense n. sp. Nr. 17.

Locality label. 142 Uschuaia, 14.XII.92.

Remarks. In 2007, Miller synonymised Gongylidiellum uschuaiense Simon 1902 under Neomaso patagonicus based on "holotype male from Terre de Fue [Tierra del Fuego], Argentina, 21794, in MNHN". The locality data provided by Miller is imprecise and does not enable us to confirm that this specimen was part of the type series. Furthermore, the original description presented by Simon clearly describes a female and Miller (2007) mentions examining a male holotype. We conclude that Miller did not see the specimen described by Simon and therefore the synonymy is incorrect; also because the female in Hamburg is clearly not a Neomaso based on the female genitalia lacking a scape.

Type material. Lectotype $q$ designated here (ZMH-A0000757).

Description. Female (lectotype). Total lenght: 1.31; cephalothorax length: 0.59 ; cephalothorax width: 0.42 . COLORATION: "pale yellow-reddish, abdomen light gray". CEPHALOTHORAX: Longer than wide (Fig. 3A); pars cephalica straight, pars thoracica sloping gradually; clypeus 3xAME; sternum as long as wide. EYES: oval, all surround by black pigment; AME minuscule, PME small, AME touching, AME-LE slightly separated, LE touching, LE-PME slightly separated, PME separated by their diameter. LEG: TmI: 0.34. ABDOMEN: Round (Fig. 3A). GENITALIA: Epiygnum with median longitudinal dark line, two elongated, oval spermathecae and copulatory ducts elongated visible through integument (Fig. 3B, C).

Male. Unknown.

Distribution. Argentina: Uschuaia.

Taxonomic note. Species from the genus Gongylidiellum are found in the Old World, except for Gongylidiellum uschuaiense. It is highly likely that this species does not belong in this genus, as already indicated by Simon when he gave the species name with a "?". Further work on Argentinian Linyphiidae is necessary before the species can be placed more accurately.

Current systematic position. Linyphiidae, Gongylidiellum uschuaiense Simon, 1902.

\section{Neriene fuegiana Simon, 1902}

Fig. 4A-C

Neriene fuegiana Simon, 1902: 17 (as Neriene fuegiana n. sp., description female).

Oedothorax fuegianus Petrunkevitch, 1911: 262 (transferred female).

Oedothorax fuegianus Miller, 2007: 244, f. 186C (female illustration, misplaced in this genus).

Type locality. Coll. Mich. 187. Süd-Feuerland, Küstenstich-Ebenen südwestlich von Kap San Pio; 27.XII.92. 

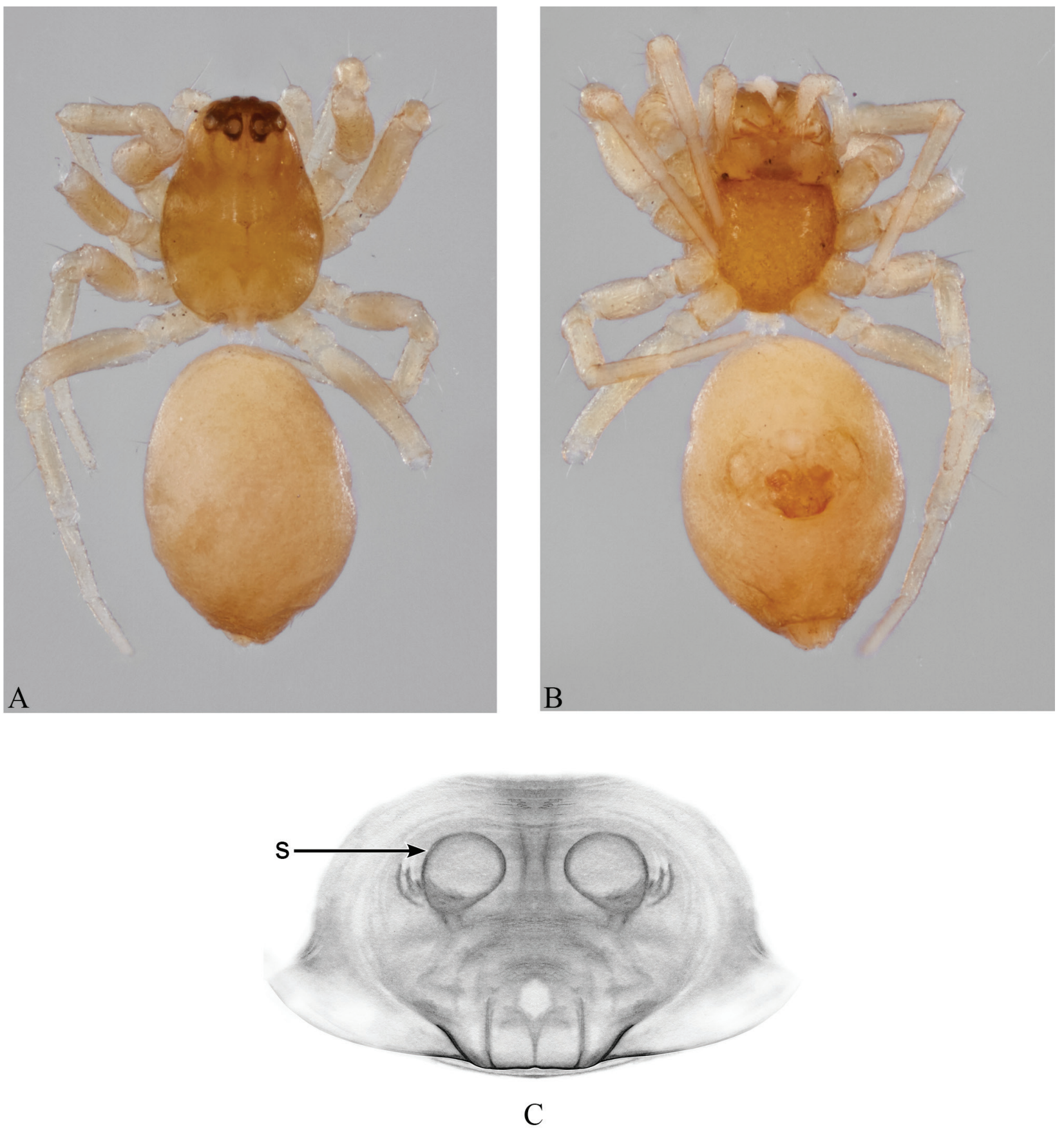

Figure 2. Minyriolus australis Simon, 1902. Female. A. Habitus, dorsal view. B. Habitus, ventral view. C. Epigynum, ventral view. Abbreviation: s: spermathecae.

Dimensions. ㅇ. long. $2,7 \mathrm{~mm}$.

Determination label. Neriene fuegiana n. sp. Nr. 20 .

Locality label. 187. Feuerld. S.K.wstl.v.Kp.S.Pio, Coll. Michaelsen. 27.XII.92.

Remarks. This species was transferred by Petrunkevitch (1911) to the genus Oedothorax. In 2007, Miller (2007) mentionned that the primary type is from Argentina, Terra de Fue [Tierra del Fuego] $54^{\circ} 15^{\prime}$ S $68^{\circ} 0^{\prime} \mathrm{W}$ (Michl., MNHN 14110, holotype female) and that this species is probably misplaced in this genus. The specimen examined by Miller is probably part of the type series but the locality data are imprecise and only Tierra del Fuego is mentionned. Miller provides illustrations of the female genitalia that correspond to the specimen held at the Hamburg Museum; however, he does not designate a lectotype and his assumption of holotype status is invalid. The specimen in Hamburg is designated as lectotype because it is evidently part of the type series and the specimen No. 14110 at the MNHN is designated as a paralectotype.

Type material. Lectotype $\uparrow$ designated here (ZMH-A0000758).

Description. Female (lectotype). Total length: 1.74; cephalothorax length: 0.59; cephalothorax width: 0.48 . 

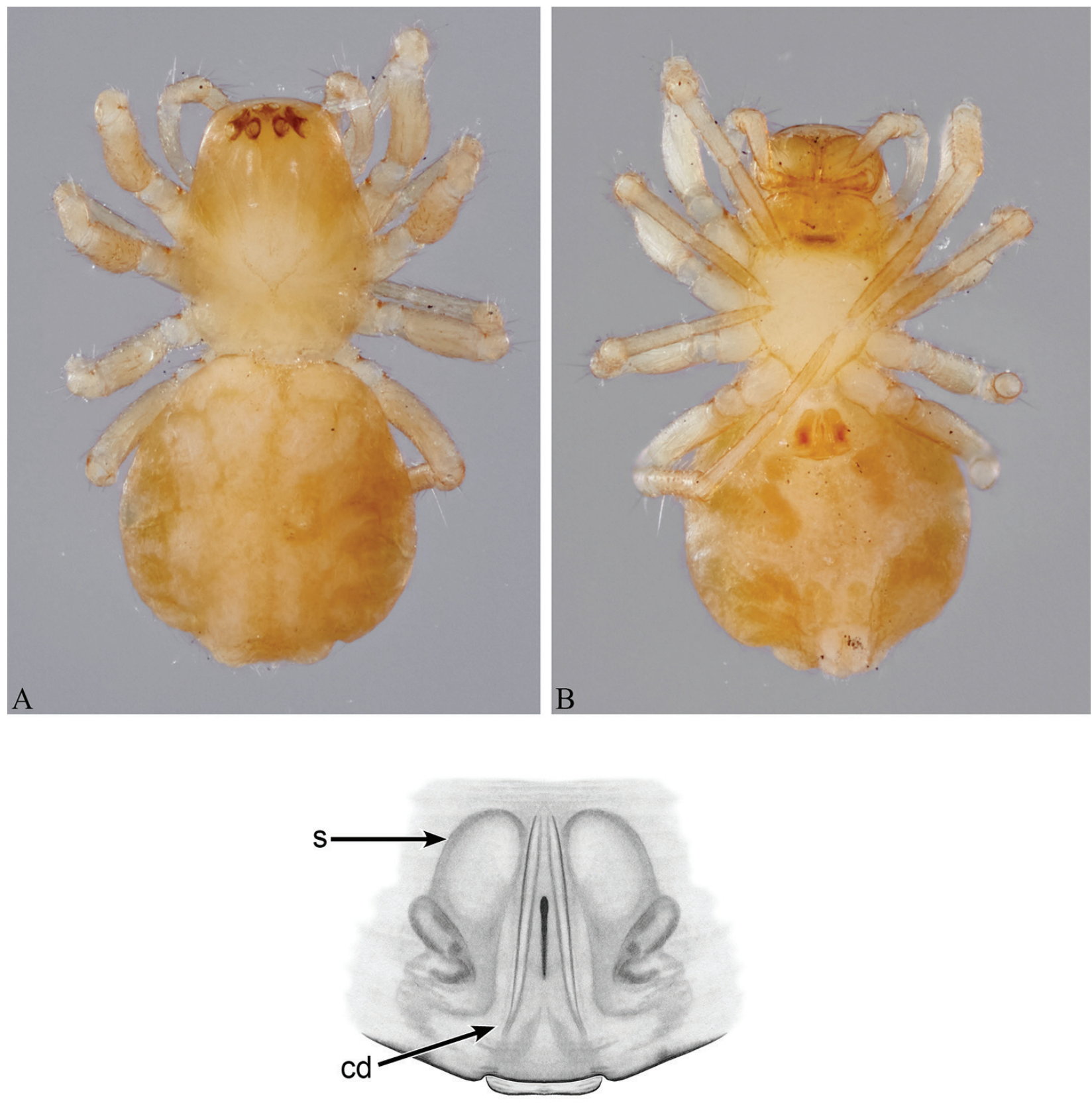

C

Figure 3. Gongylidiellum uschuaiense Simon, 1902. Female. A. Habitus, dorsal view. B. Habitus, ventral view. C. Epigynum, ventral view. Abbreviations: cd: copulatory ducts, s: spermathecae.

COLORATION: "cephalothorax pale yellow, eyes with thin black ring. Abdomen dorsally white, both sides with wide dark indistinct pattern, median line complete, with 4 or 5 slightly brownish arched transverse lines, ventrally pale reddish-brown." CEPHALOTHORAX: Longer than wide (Fig. 4A), pars cepalica slightly arched, pars thoracica slooping gradually; clypeus 2XAME; sternum as lons as wide. EYES: round, all surround by black pigment and about the same size; AME touching, AME-LE separated by their radius, LE touching, LE-PME separated by their radius, PME separated by their diameter. LEG: Tm I: 0.45. ABDOMEN: Oval. GENITALIA: Epigynum with triangular median protrusion, two large, oval spermathecae visible through integument (Fig. 4B, C).

Male. Unknown.

Distribution. Chile, Kap San Pio.

Current systematic position. Linyphiidae, Oedothorax fuegiana Simon, 1902.

\section{Neriene michaelseni Simon, 1902}

Neriene michaelseni Simon, 1902: 18 (as Neriene michaelseni n. sp., description female). 

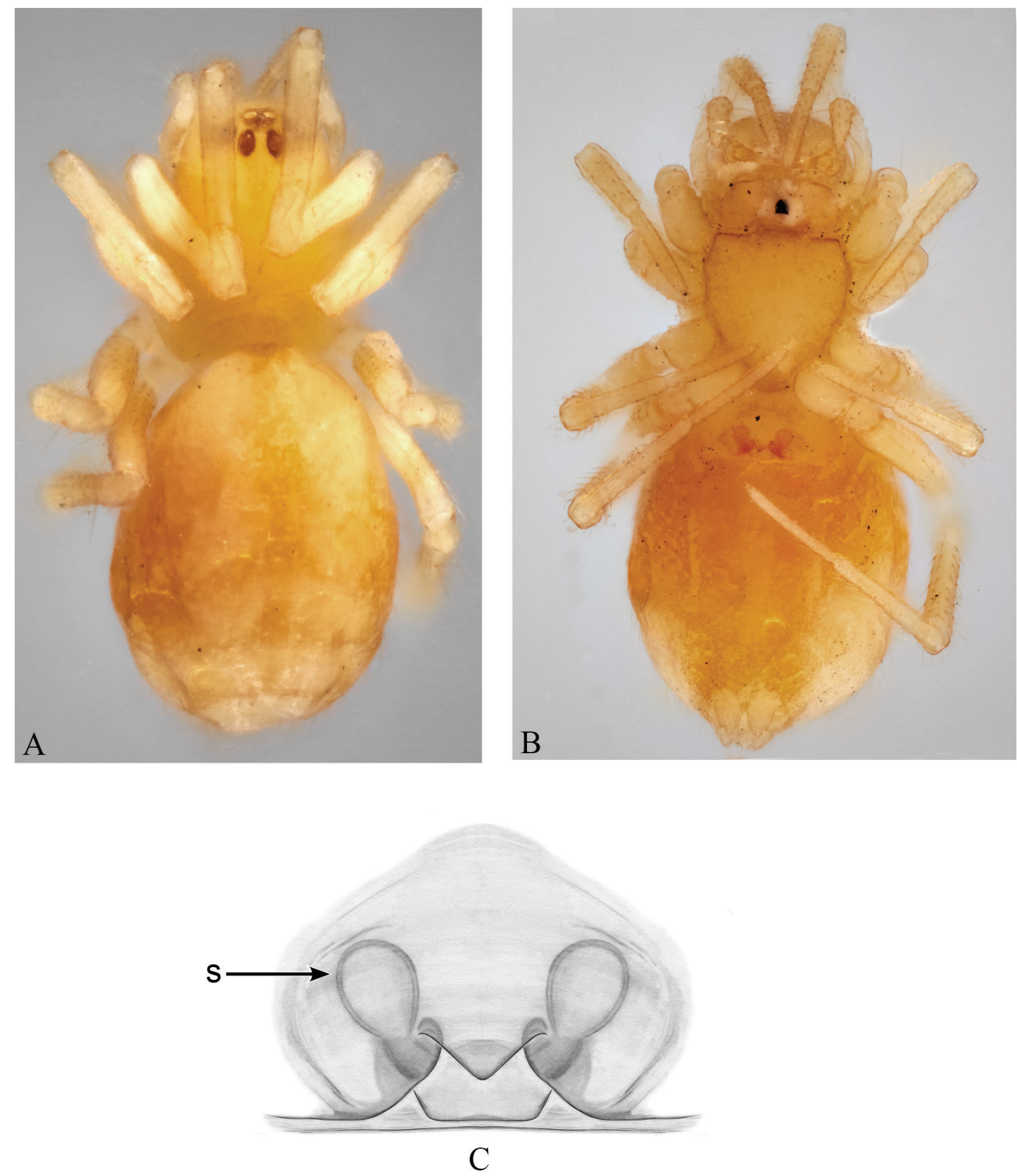

Figure 4. Neriene fuegiana Simon, 1902. Female. A. Habitus, dorsal view. B. Habitus, ventral view. C. Epigynum, ventral view. Abbreviation: s: spermathecae.

Type locality. Coll. Mich. 140. Süd-Feuerland, Uschuaia, Wald, unter vermodernden Baumstümpfen; 30.X.92. Coll. Mich. 141. Süd-Feuerland, Uschuaia, Land; 14.XI.92.

Dimensions. 9 . long. $2,4 \mathrm{~mm}$.

Determination label. Neriene michaelseni n. sp. Nr. 22. Locality label 1. 140. Uschuaia; Wald. Coll. Michaelsen 30.X.92.
Locality label 2. 141. Uschuaia. Coll. Michaelsen 14.XI.92.

Type material. Syntypes $1 \hat{\sigma}$ penultimate (ZMHA0000759); 7 우 penultimate (ZMH-A0000760).

Remarks. Neriene michaelseni Simon 1902 was synonymised by Miller (2007:23) under Laminacauda plagiata (Tullgren 1901). He based his synonymy on the examination of a female specimen: [holotype fe- 
male from Teiu de fue [Tierra del Fuego], [Argentina?] (Michl.), in MNHN]. Here again, Miller (2007) probably examined a syntype but this is difficult to know since the locality data provided are imprecise. Simon clearly mentions that he studied specimens from two different habitats. The specimens at the ZMH are obviously syntypes, but they are all juveniles, therefore we believe it is better to accept Miller (2007) synonymy to avoir further taxonomical confusion. Since no lectotype was properly designated by Miller, the ZMH specimens are still considered syntypes.

Current systematic position. Linyphiidae, Laminacauda plagiata (Tullgren, 1901).

\section{Clitistes Simon, 1902}

\section{Simon 1902: 20 (Gen. Clitistes nov.)}

Note. Simon described the genus Clitistes and placed it in the family Linyphiidae. The description is rather short: he mentions that the genus is closely related to Clitolyna but differs by the eye arrangement, shorter clypeus, abdominal setae and shorter palps. The genus Clitolyna was synoymised by Miller (2007) under Sphecozone. After finding and studying the holotype, it is evident that Clitolyna does not belong in the family Linyphiidae and should in fact be placed in the family Dictynidae. An interesting note by Simon (translated from German): "The large hydrofuge hairs, which are attached to the body surface, and which are very similar to those of Hahnia, seem to indicate a semi-aquatic way of life. The very large stigmata, which are well separated from the spinneret base, are also very similar to those of Hahnia".

\section{Clitistes velutinus Simon, 1902}

Fig. $5 \mathrm{~A}-\mathrm{C}$

Clitistes velutinus Simon, 1902: 20 (as Clitistes velutinus n. sp., description female).

Type locality. Coll. Mich. 178. Süd-Feuerländ. Arch., Isl. Navarin, Puerto Toro, Wald; 19.XII.92.

Dimensions. 9 . long. $2,5 \mathrm{~mm}$.

Determination label. Clitistes velutinus n. sp. Nr. 25.

Locality label. 178. Navarin, Puerto Toro, Wald, Coll. Michaelsen 19.XII.92.

Remarks. The female specimen deposited in the ZMH is clearly the specimen described by Simon, as evidenced by original data found on the label. Miller (2007: 259) declared the genus Clitistes and the single species Clitistes velutinus as a nomina dubia, which is incorrect based on the re-discovery of the type specimen.

Description. Female (lectotype). Total length: 2.89; cephalothorax length: 1.05; cephalothorax width: 0.96.

Type material. Lectotype + , designated here (ZMH-A0000761).
COLORATION (based on original description, translated from Latin): "cephalothorax dark brown, pars cephalica slightly paler, pars thoracica with thin black margin. Abdomen dorsally dark yellow-bluewish, medially with wide, darker band, anterior margin paler, in the middle part, three transverses, angular arches, apically with small spots; ventrally, dark yellow. Femur apically with brown ring". CEPHALOTHORAX: Pyriform, longer than wide (Fig. 5A), pars cephalica flat, pars thoracica sligthly slooping; clypeus 2 XAME; cheliceral promargin with three teeth, retromargin with two small denticles; sternum slightly longer than wide. EYES: round; AME smallest, AME slightly separated, AME-LE separated by their diameter, LE touching, LEPME separated by their diameter, PME separated by $2 x$ their diameter. LEGS: macrosetae present. ABDOMEN: Oval. GENITALIA: Epigynum with two small, triangular copulatory openings, two large, rounded spermathecae and coiled copulatory ducts visible through the integument (Fig. 5B, C).

Male. Unknown.

Distribution. Chile, Puerto Toro.

Current systematic position. Transferred to Dictynidae, Clitistes velutinus Simon, 1902

\section{Zilephus Simon, 1902}

Zilephus Simon, 1902: 22 (Gen. Zilephus nov.)

Note. Here again, Simon's description of the genus is rather short and he mentions that the genus resembles $\mathrm{Mi}$ croneta but differs by eye arrangment, clypeus and the granulation of the cephalothorax.

\section{Zilephus granulosus Simon, 1902}

Fig. 6A-C

Simon 1902: 22 (as Zilephus granulosus n. sp. description female)

Type locality. Coll. Mich. 140. Süd - Feuerländ, Uschuaia, Wald, unter vermodernden Baumstämmen; 30. X. 92.

Dimensions. ${ }^{\top}$.long. $2 \mathrm{~mm}$.

Determination label. Zilephus granulosus n. sp. Nr. 27.

Locality label. 140. Uschuaia, Wald. Coll. Michaelsen. 30.X.92.

Remarks. The data from the labels found with the ZMH specimen matches with the information presented by Simon in his paper. In the original description, the specimen described is supposed to be a male (the male symbol is written at the beginning of the description) but the description mentions the genital plate: "Area genitalis rufula, plana, obtuse triquetra, postice plagula transversa parva et nitida munita" and does not include the male palp; hence we conclude that the male symbol is a typographical error and the type specimen is a female. Miller 

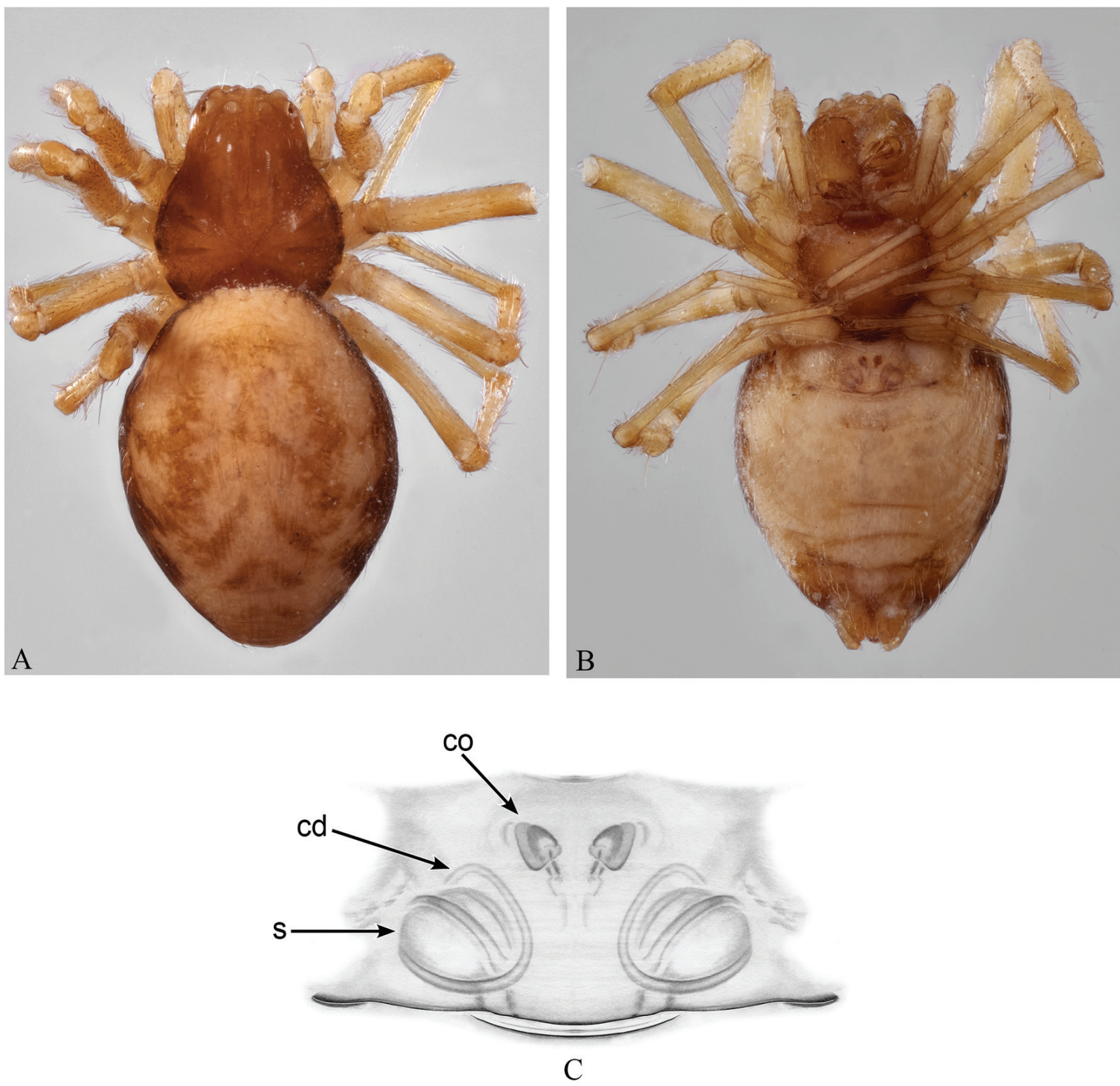

Figure 5. Clitistes velutinus Simon, 1902. Female. A. Habitus, dorsal view. B. Habitus, ventral view. C. Epigynum, ventral view. Abbreviation: cd: copulatory ducts, co: copulatory openings, s: spermathecae.

(2007: 259) erroneously declared the genus Zilephus and the species Zilephus granulosus nomina dubia.

Type material. Lectotype $q$ designated here (ZMH-A0000762).

Description. Female (lectotype). Total length: 2.32; cephalothorax length: 0.87 ; cephalothorax width: 0.71 . COLORATION: (from original description, translated from Latin): "cephalothorax blackish or dark olive. Abdomen dorsally white, ornated with median broad band bluntely trilobate, and apically pointed, with black and white spots obliquely paired, ventrally reddish brown. Femur yellow, tibia and metatrsi apically with small brown ring; tibia IV with medially and apically small brown ring." CEPHALOTHORAX: Pyriform, longer than wide (Fig. 6A), pars cephalica slight- ly procurved, pars thoracia sloping smoothly; covered with small granualtion; clypeus 1xAME; cheliceral promargin with three teeth, retromargin not observed; sternum slightly longer than wide. EYES: Eight eyes surrounded by black rings, AME smallest, touching, AME-LE separated by their diameter, LE touching, LE-PME separated by their radius, PME separated by their radius. LEGS: Tm I not observed. ABDOMEN: Oval. GENITALIA: Epigynum flat with two small, rounded spermathecae visible through the integument (Fig. 6B, C).

Male. Unknown.

Distribution. Argentina: Uschuaia

Current systematic position. Linyphiidae, Zilephus granulosus Simon, 1902. 

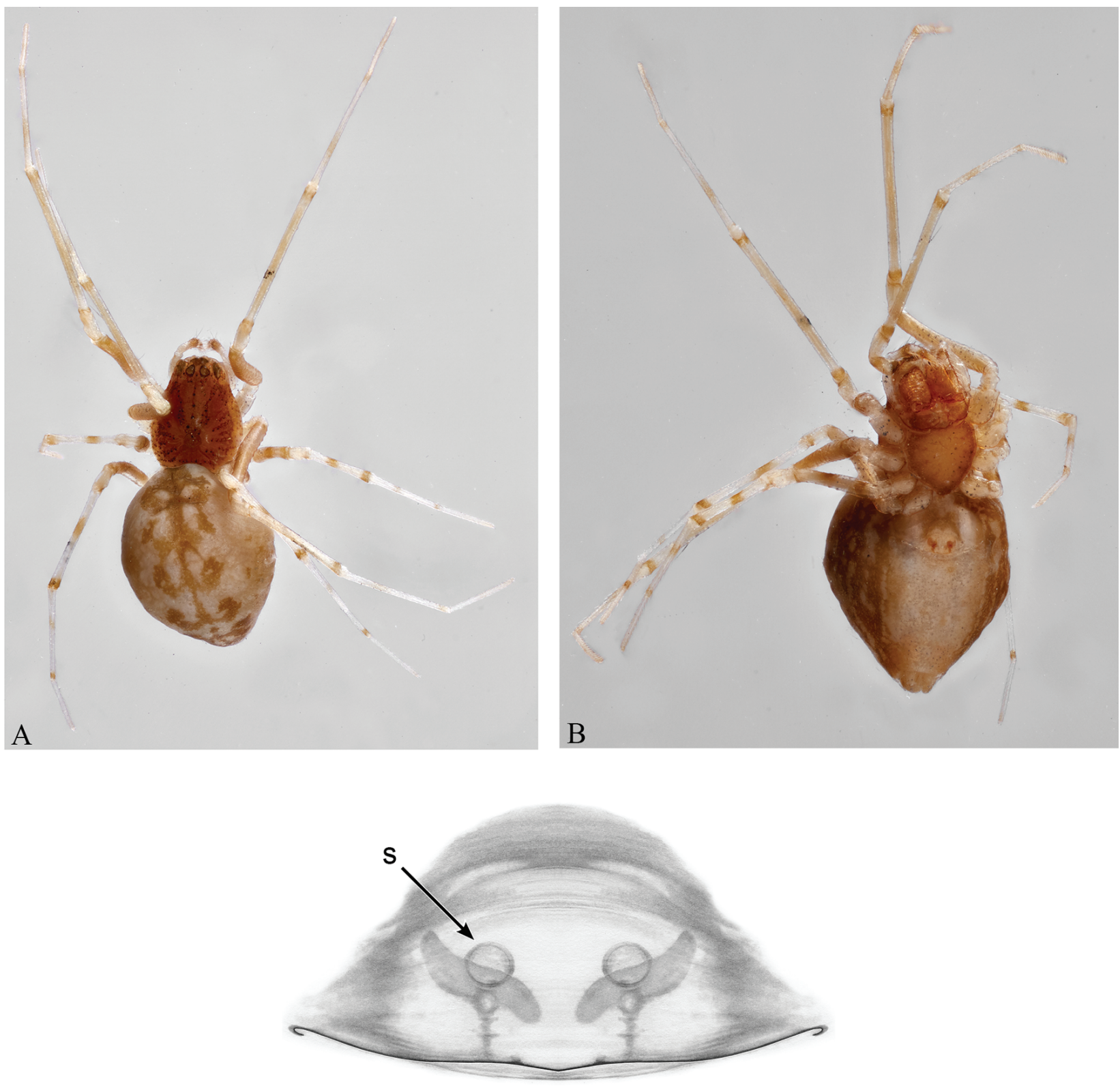

C

Figure 6. Zilephus granulosus Simon, 1902. Female. A. Habitus, dorsal view. B. Habitus, ventral view. C. Epigynum, ventral view. Abbreviation: s: spermathecae.

\section{Family Theridiidae}

\section{Enoplognatha triangulifera Simon, 1902}

Theridion ventrosum Nicolet, 1849: 536 (description female). Theridion recurvatum Tullgren, 1901: 191 (description juvenile).

Enoplognatha triangulifera Simon, 1902: 14 (as Enoplognatha triangulifera $\mathrm{n}$. sp., female description).

Anelosimus recurvatus Levi, 1962: 12 (transferred female from Theridion, synonymy).

Anelosimus recurvatus Levi, 1963: 45, f. 49-52 (female, description male).
Anelosimus ventrosus Levi, 1967: 13 (transferred female from Theridion, synonymy male).

Anelosimus recurvatus Schiapelli \& Gerschman, 1974: 86, f. 36-38 (male and female redescription).

Selkirkiella ventrosa Agnarsson, 2004: 476 (transferred male and female from Anelosimus).

Type locality. Coll. Mich. 165. Süd-Feuerland, Harberton Harbour (Puerto Bridges); 10. I. 93. Coll. Mich. 187. Süd-Feuerland, Küstenstrich-Eben westlich von Kap San Pio; 27.xii.92.

Dimensions. $q$ long. $4 \mathrm{~mm}$.

Determination label. Enoplognatha triangulifera n. sp. Nr. 15 . 
Locality label 1 (with 2 ㅇ). 165. Puerto Bridges; Wald. Coll. Michaelsen. 10.I.93.

Locality label 2 (with 2 q). 187. Feuerld. S.K.wstl.v.Kp.S.Pio. Coll. Michaelsen. 27.xii.92.

Type material. Syntypes 4ㅇ (ZMH-A0000767).

Remarks. Levi (1962: 12) synonymised Enoplognatha triangulifera Simon 1902 under Anelosimus recurvatus (Tullgren 1901). Levi (1963: 45) also mentions examining the female type from the Paris Museum and states that the four ZMH specimens are syntypes. We refrain from designating lectotypes until the specimens in Paris can be reviewed.

Current systematic position. Theridiidae, Selkirkiella ventrosa (Nicolet, 1849)

\section{Family Clubionidae \\ Subfam. Anyphaeneae \\ Tomopisthes Simon}

\section{Tomopisthes kraepelini Simon, 1902}

\section{Simon 1902: 31 (as Tomopisthes Kraepelini n. sp.)}

Type locality. Coll. Mich. 75. Süd-Patagonien, Punta Arenas, unter Steinen und Baumstämmen; IX. 92.

Dimensions. $\circ$. long. $13 \mathrm{~mm}$.

Determination label. Tomopisthes Kraepelini n. sp. Nr. 49.

Locality label. 75. Magelh. Str., Punta arenas; Coll. Michaelsen. IX.92.

Type material. Syntype $\bigcirc$ (ZMH-A0000768).

Remarks. This species was synonymised under $\mathrm{Sa}$ nogasta approximata (Tullgren 1901) by Ramírez (2003: 172) based on a specimen from MHNP 20723, female holotype. The specimen in the MHNP is probably part of the type series but this is difficult to know since Simon did not mention how many specimens he examined. Ramírez did not formely designate a lectotype and the holotype assumption is invalid. The ZMH specimen remains a syntype until all specimens are re-examined (see discussion).

Current systematic position. Anyphaenidae, Sanogasta approximata (Tullgren, 1901).

\section{Tomopisthes conspersus Simon, 1902}

Simon 1902: 33 (as Tomopisthes conspersus n. sp.)

Type locality. Coll. Mich. 81. Süd-Patagonien, Punta Arenas; X.-XII.92. (H. Michelsen leg.).

Dimensions. + . long. 6-7 mm.

Determination label. Tomopisthes conspersus n. $\mathrm{sp}$. Nr. 52.

Locality label. 81. Magelh. Str., Punta Arenas; Coll. Michaels. Herbst 92 (Michaelsen 1.).

Type material. Syntype + (ZMH-A0000769).

Remarks. Ramírez (2003:154) synonymised Tomopisthes conspersus based on a specimen from MHNP
21816, female holotype. The specimen in the MHNP is probably part of the type series but Ramírez did not formely designate a lectotype. The holotype assumption is invalid and the ZMH specimens remain syntypes until all specimens are re-examined (see discussion).

Current systematic position. Anyphaenidae, Sanogasta maculosa (Nicolet, 1849).

\section{Tomopisthes injucundus Simon, 1902}

Tomopisthes injucundus Simon 1902h: 33 (as Tomopisthes injucundus n. sp., description female)

Type locality. Coll. Mich. 80. Süd-Patagonien, Punta Arenas; 25.II.93. Coll. Mich. 141. Süd-Feuerland, Uschuaia; 14.XI.92 Coll. Mich. 165. Süd-Feuerland, Harberton Harbour (Puerto Bridges), Wald, 10.I.93. Coll. Mich. 174. Süd-Feuerland, Arch. Isl. Picton, Banner Cove, 26.XII.92. Coll. Mich. 193. Süd-Feuerland, Puerto Pantalon, 2.I.93.

Dimensions. + . long. $6 \mathrm{~mm}$.

Determination label. Tomopisthes injucundus n. sp. Nr. 53.

Locality label (with 29). 80. Punta Arenas, Mich. 25.II.93.

Locality label (with $2 \circ, 2 \hat{)}) .141$. Uschuaia, Coll. Michaelsen. 14.XI.92.

Locality label (with 29). 174. Isl. Picton, Coll. Michaelsen. 26.XII.92.

Locality label (with 5q). 165. Puerto Bridges, Coll. Michaelsen. Wald, 9.I.93.

Locality label (with 19). 193. Feuerland, Puerto Pantalon; Coll. Michaelsen. 2.I.93.

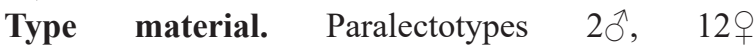
(ZMH-A0000771).

Remarks. Ramírez (2003: 154) synonymised Tomopisthes injucundus under Sanogasta maculosa (Nicolet, 1849) based on female lectotype, three females and one male paralectotypes that he designated from specimens from "Tierre del Fuego, MHNP 21782 (the male paralectotype belongs to a different, presumably undescribed Sanogasta species)". The specimen in the Paris Museum are probably part of the type series and were designated as such by Ramírez. Therefore, the ZMH specimens are now paralectotypes.

Current systematic position. Anyphaenidae, Sanogasta maculosa (Nicolet, 1849).

\section{Tomopisthes modestus Simon, 1902}

Tomopisthes modestus Simon 1902: 35 (as Tomopisthes modestus n. sp., description female)

Type locality. Female, Coll. Mich. 76. Süd-Patagonien, Punta Arenas, unter Baustämmen; 15.III.93.

Dimensions. 9 . long. $5 \mathrm{~mm}$.

Determination label. Tomopisthes modestus n. sp. Nr. 55. 
Locality label. 76. Magelh. Str., Punta arenas; IX.92. Type material. Syntype $\bigcirc$ (ZMH-A0000770).

Remarks. Ramírez (2003: 154) synonymised Tomopisthes modestus under Sanogasta maculosa (Nicolet, 1849) based on female holotype from Chile, Punta Arenas, IX.1892, Michaelsen coll., examined in MHNP. The specimen in the Paris Museum is probably part of the type series but Ramírez did not designate a lectotype. The holotype assumption is invalid and the $\mathrm{ZMH}$ specimen remains as a syntype until all specimens are re-examined (see Discussion).

Current systematic position. Anyphaenidae, Sanogasta maculosa (Nicolet, 1849).

\section{Family Agelenidae}

Subfam. Cybaeinae

\section{Rubrius radulifer Simon, 1902}

Fig. $7 \mathrm{~A}-\mathrm{D}$

Rubrius radulifer Simon, 1902: 36 (Rubrius radulifer n. sp., description female and male).

Calacadia radulifera Exline, 1960: 618 (Transferred female from Rubrius).

Type locality. Coll. Mich. 30. Chile, Putabla bei Valdivia; 20.IV.93.

Coll. Mich. 38. Chile, Valdivia; 31.III.93.

Determination label. Rubrius radulifer n. sp., Nr. 58. Locality label 1 (with +). 30. Valdivia, Putabla; Coll. Michaelsen. 20.IV.93.

Locality label 2 (with §ึ). 38. Valdivia. Coll. Michaelsen. 31.III.93.

Dimensions. ․ long. $12-15 \mathrm{~mm}$. $\curvearrowright .10 \mathrm{~mm}$

Remarks. The ZMH specimens correspond to a juvenile female and an adult male that clearly come from the type series. This species was transferred by Exline (1960) to Calacadia radulifera (Simon 1902). Exline presented a description of both male and female but it is difficult to determine which specimens she examined. She mentions on a foot note on page 168 that Dr. Levi examined the type in the MNHN but unfortunately no data are given and it is difficult to assess if these specimens were part of the type series. This species has never been illustrated before and we can only present the description of the male since the $\mathrm{ZMH}$ female specimen is a juvenile.

Type material. Lectotype $\widehat{\delta}$ designated here, paralectotype + (juvenile) (ZMH-A0000790).

Description. Male (Lectotype). Total length: 6.04; cephalothorax length: 3.36; cephalothorax width: 2.38 . COLORATION (from original descrition, translated from Latin): "Cephalothorax reddish-yellow, frontal region of pars cephalica darker, with dark oblique broad band on both sides, with very intricate dentate V-form pattern, pars thoracica with marginal line slightly black, radiating line barely visible. Abdomen, yellow-reddish, with brown reticulate pattern, middle band pale with dentate pattern, border dark and sinuous. Legs yellow-reddish, femora and tibiae with two dark-olive rings, metatarsi and tarsi anteriorly darker". CEPHALOTHORAX: Pear-shaped, longer than wide (Fig. 7A); pars cephalica slightly convexe; pars thoracica sloping gradually; fovea longitudinal. Cheliceral promargin and retromargin with two teeth. Sternum broad oval. EYES: AME smaller, slightly separated, LE touching, PME separated by their diameter. LEGS: Trochanter notched; anterior tibia with 4 pairs of ventral spines. ABDOMEN: Oval. GENITALIA: Patella retrolaterally with short, stout protuberance; tibia retrolaterally bears a short fleshy basal process and distally a blunt tibial process, with oblique carina; cymbium large and elongated (Fig. 7D). Bulb with large tegulum; median apophysis hooked; terminal apophysis large surrounding the embolus except at the tip; embolus rising from the basal retrolateral side of the tegulum; conductor membranous, arising retrolaterally (Fig. 7C).

Distribution. Chile, Valdivia.

Current systematic position. Desidae, Calacadia radulifera Exline, 1960.

\section{Rubrius paganus Simon, 1902}

Rubrius paganus Simon, 1902: 37 (Rubrius paganus n. sp, description female and male).

Rubrius annulatus Lehtinen, 1967: 263, f. 159 (female illustration, female and male synonymy).

Rubrius annulatus Roth, 1967: 329, pl. 52, f. 13 (female redescription).

Rubrius paganus Roth, 1967: 332, pl. 52, f. 19-20 (female and male redescription).

Type locality. Coll. Mich. 28. Chile, Chamil-chamil bei Valvidia; 23.IV.93.

Dimensions. ․ . long. 10-12 mm. ㄱ. $8 \mathrm{~mm}$.

Determination label. Rubrius paganus n. sp. Nr. 59.

Locality label. 28. Valvidia, Chamilchamil. Coll. Michaelsen. 23.IV. 93.

Type material. Paralectotypes juveniles $1 \delta 1 q$ (ZMH-A0000764).

Remarks. Rubrius paganus Simon 1902 was synonymised under Rubrius annulatus F.O. Pickard-Cambridge, 1899 by Lethinen (1967: 263) based on a ${ }^{1}$ ㅇ "Rubrius paganus" held at the Paris Museum. Roth (1967: 332) redescribed Rubrius paganus from some specimens "(male lectotype, six female lectoparatypes, and two immature specimens from Valdiva, Chile, No. 18228)" at the MNHN. It is difficult to know if the specimens examined by Lethinen and Roth were part of the type series since the locality data are incomplete. Nonetheless, since Roth designated a lectotype for the species Rubrius paganus Simon 1902 from the Paris Museum. 

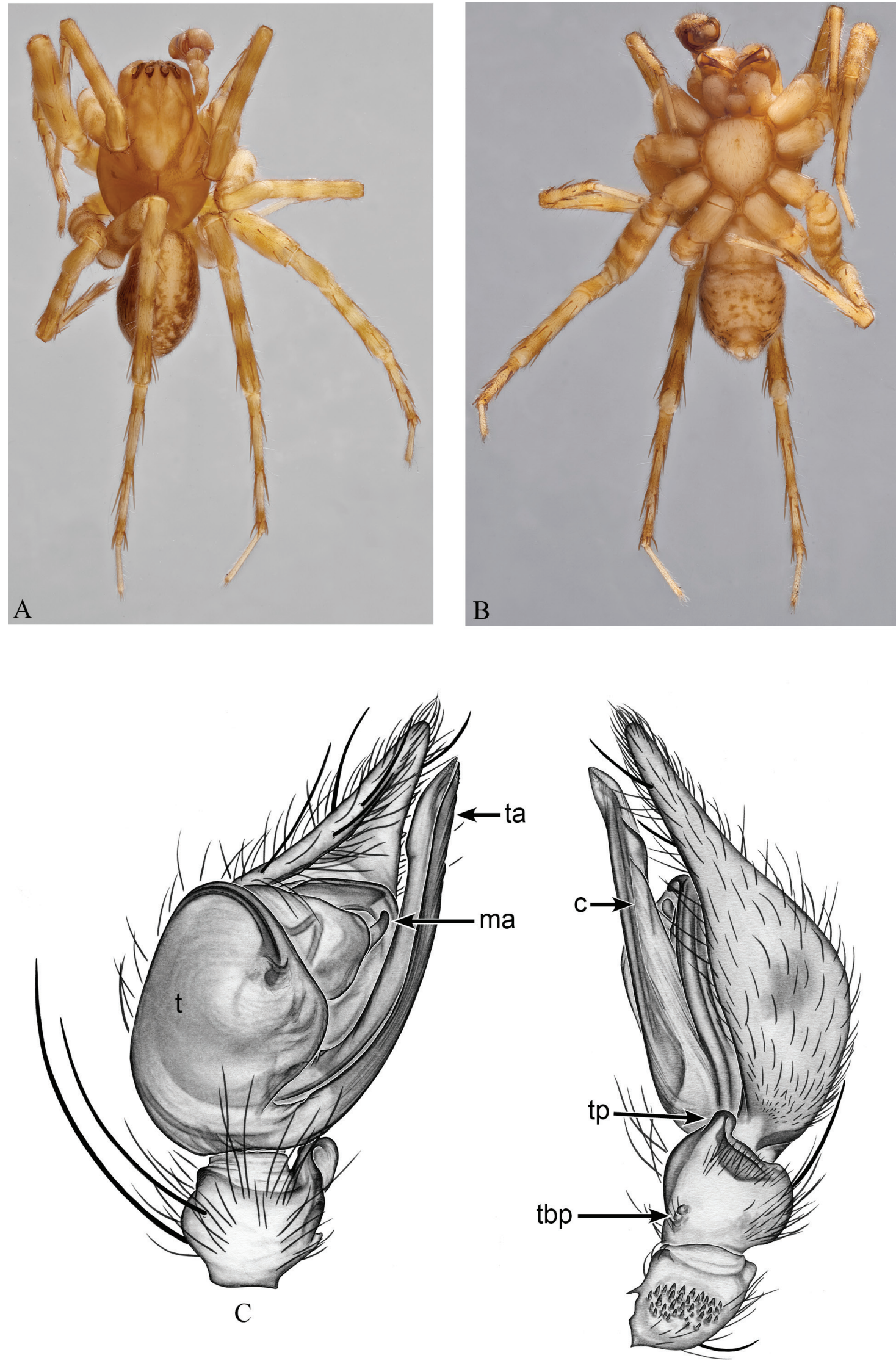

$\mathrm{D}$

Figure 7. Rubrius radulifer Simon, 1902. Male. A. Habitus, dorsal view. B. Habitus, ventral view. C. Palp, ventral view. D. Palp, prolateral view. Abbreviations: c: conductor, ma: median apophysis, t: tegulum, ta: terminal apophysis, tbp: tibial basal process, tp: tibial process. 
Current systematic position. Amaurobiidae, Rubrius annulatus F.O. Pickard-Cambridge, 1899.

\section{Family Hahniidae}

\section{Hahnia michaelseni Simon, 1902}

Fig. $8 \mathrm{~A}-\mathrm{D}$

Hahnia michaelseni Simon, 1902: 39 (Hahnia Michaelseni n. sp. description female).

Hahnia michaelseni Vellard, 1958: 136, f. 18-25 (female, description male, doubtful identification).

Hahnia michaelseni Lehtinen, 1967: 455, f. 376 (female).

Hahnia michaelseni Schiapelli \& Gerschman, 1974: 89, f. 34-35 (female, doubtful identification).

Type locality. Coll. Mich. 187. Süd-Feuerland, Küstenstrich-Eben westlich von Kap San Pio; 27.XII.92.

Dimensions. . long. $2 \mathrm{~mm}$.

Determination label. Hahnia Michaelseni n. sp., Nr. 61. Locality label. 187. Feuerld.S.K. wstl.v. Kp. S. Pio. Coll. Michaelseni. 27.XII.92.

Remarks. In 1958, Vellard described a female and a male based on specimens from Rusfin, that he believed was the species Hahnia michaelseni but he mentions (p.137) that he was not able to see the type and that there were some significant differences: "les différences de formule oculaires sont peut-être plus significatives. N'ayant pu comparer nos examplaires au type de Hambourg.... Il est bien difficile d'apprécier la valeur de ces différences". Lethinen (1967: fig. 376) also illustrated a female but did not mention where the specimen came from. Finally, in 1974 Shiapelli and Gerschman redescribed the species based on a single female from Puerto San Carlos. Multiple authors (Vellard 1949, Lethinen 1967, Shiapelli and Gerschman 1974) have redrawn this species but nobody seems to have re-examined the type and the only illustration that matches with the specimens held at the ZMH is the illustration presented by Lethinen (1967). There is a possibility that the specimens examined by Vellard and Shiapelli and Gerschman (1974) are of another species. The specimen found at the $\mathrm{ZMH}$ matches the description in locality data and size. It is designated here as the lectotype.

Type material. Lectotype $\uparrow$ designated here (ZMH-A0000763).

Description. Female (lectotype). Total length: 2.26; cephalothorax length: 1.04 ; cephalothorax width: 0.78 . COLORATION: (from original description, translated from Latin) "cephalothorax smooth, dark olive-brown, thoracic part with thin, barely distinct black border. Abdomen oval, dark gray, decorated anteriorly with longitudinal line, posteriorly with four transversal lines, slightly curved". CEPHALOTHORAX: Pear-shaped, fovea longitudinal (Fig. 8A); pars cephalica not elevated, pars thoracia slooping gradually. Cheliceral teeth not observed. Sternum narrowly truncated (Fig. 8B). EYES: AME smallest (Fig. 8C). ABDOMEN: Oval. Spinnerets in straight row (Fig. 8B). LEGS: Spines present. GENITALIA: Epigynum with central, longitudinal opening (Fig. 8D).

Male. Unknown.
Distribution. Kap San Pio.

Current systematic position. Hahniidae, Hahnia michaelseni Simon, 1902.

\section{Bigois antarctica Simon, 1902}

Fig. 9A-F

Bigois antarctica Simon, 1902: 40 (Bigois antarctica n. sp., description female).

Bigois antarctica Birabén, 1957: 4, f. 1-8 (female, description male).

Amaloxenops translata Schiapelli \& Gerschman, 1959: 132 (new name for Birabén's material, believed misidentified).

Intihuatana antarctica Lehtinen, 1967: 240, f. 372-373 (transferred male and female to Intihuatanan n. gen.).

Type locality. Coll. Mich. 150. Süd-Feuerland, Uschuaia, unter Steinen und zwischen Steingeröll; 15.XI.92. Coll. Mich. 178. Süd-Feuerland, Arch., Isl. Navarin, Puerto Toro, Wald; 19.XII.92. Coll. 193. Süd-Feuerland, Puerto Pantalon; 2.I.93.

Dimensions. ㅇ. long. 1,3 mm.

Determination label. Bigois antarctica n. sp. Nr. 62 .

Locality label vial 1 (with 1 + ). 193. Feuerland, Puerto Pantalon; Coll. Michaelsen. 2.I.93.

Locality label vial 2 (with $1 \circlearrowleft$ ). 150. Uschuaia 15.XI.92.

Locality label vial 3 (with 1 ) ). 178. Navarin, Puerto Toro, Wald. Coll. Michaelsen. 19.XII.92.

Type material. Lectotype 19 designated here, paralectotypes $1 \hat{\jmath}, 1 \bigcirc(\mathrm{ZMH}-\mathrm{A} 000765)$.

Remarks. In 1957, Birabén redescribed the species based on a female topotype from Uschuaia and a male allotype from Bariloche, $1600 \mathrm{~km}$ away from Uschuaia. Shiapelli and Gerschman published a paper on the characters of the genus Bigois (1959) and did not agree with Birabén's redescription. Based on his illustration and description, they suggested that his species should be placed in Amaloxenops and named it A. translata Shiapelli \& Gerschman 1959. Shiapelli and Gerschman (1959) did not examine the type in Paris, instead Prof. M.E. Galiano reviewed and drew the illustration on which they based their observations. As mentioned by Lethinen, the confusion is based on the fact that Prof. M.E. Galiano probably saw the wrong type. Lethinen (1967) mentions that the original material of Simon (op. cit.) includes four different species from three samples. One sample is in the Paris Museum and labelled Bigois antarctica, one is in Hamburg as Bigois Antarctica, and one sample is preserved in Paris and labelled Hahnia antarctica. Lethinen (1967: 240) states that "The tube labelled $B$. antarctica in Paris contains a single male of a Neohahnia sp. The sample in Hamburg consists of the true B. antarctica only, and it is curious that Simon did not mention the male at all. The other sample in Paris included only females of $B$. antarctica, but numerous females and males of an undescribed species of 

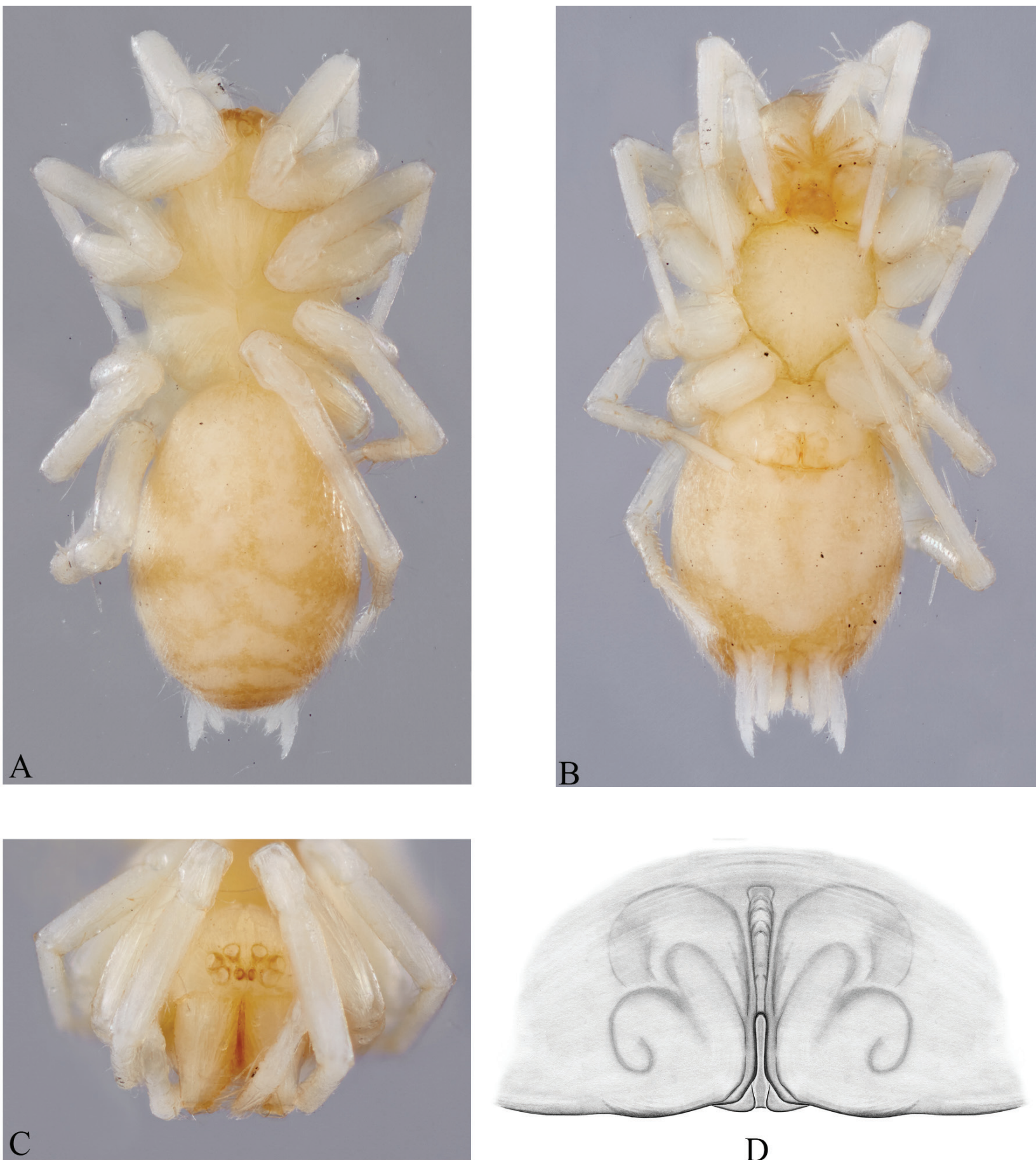

$\mathrm{D}$

Figure 8. Hahnia michaelseni Simon, 1902. Female. A. Habitus, dorsal view. B. Habitus, ventral view. C. cephalothorax, frontal view. D. Epigynum, ventral view.

Hahnia and even a juvenile specimen of an unknown twoclawed spider with rather long spinnerets". All the data from the specimens held at the Hamburg Museum correspond with the original publication and the specimens are designated here as lectotype and paralectotypes.

Description. Female (lectotype). Total length: 1.5; cephalothorax length: 0.68 ; cephalothorax width: 0.53 . COLORATION: (from original description, translat- ed from Latin): "pale yellow-reddish, abdomen white opaque". CEPHALOTHORAX: Pear-shape, longer than wide (Fig. 9A); pars cephalica not elevated, pars thoracica slooping gradually. Cheliceral teeth not observed. Sternum widely truncate posteriorly. EYES: AME minute. Legs: Spines absent. ABDOMEN: Oval (Fig. 9A); spinnerets in a straight row. GENITALIA: Epigynum with small central copulatory openings, widely separated (Fig. 9D). 

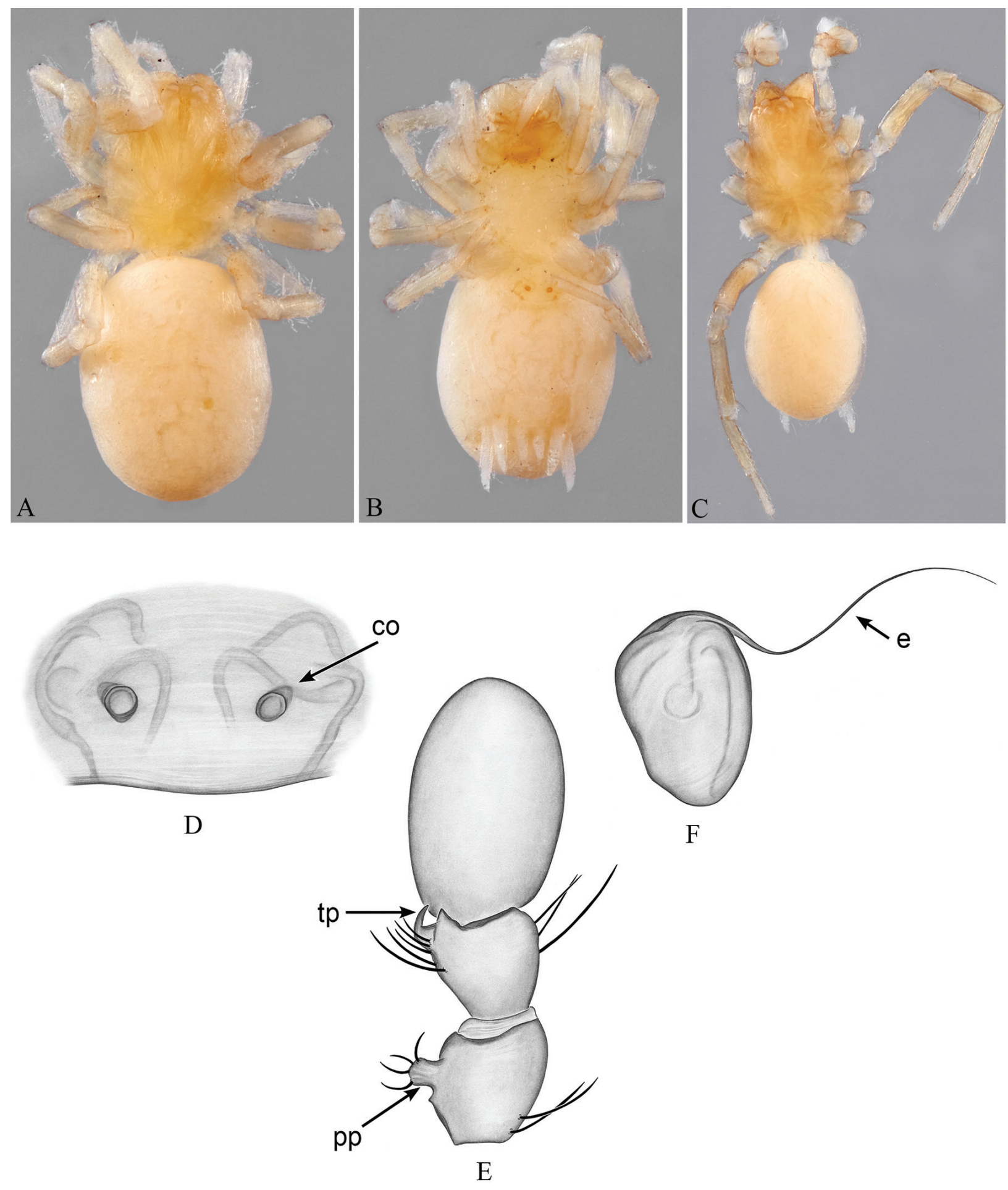

Figure 9. Bigois antarctica Simon, 1902. A. Female, habitus, dorsal view. B. Female habitus, ventral view. C. Male habitus, dorsal view. D. Epigynum, ventral view. E. Palp, dorsal view. F. Bulb and embolus, ventral view. Abbreviations: co: copulatory openings, e: embolus, pp: patellar process, tp: tibial basal process.

Male. (paralectotype). Total length: 1.52; cephalothorax length: 0.73; cephalothorax width: 0.55 .

CEPHALOTHORAX: As in female (Fig. 9C). Cheliceral teeth not observed. Sternum as in female. EYES and ABDOMEN: As in female. GENITALIA (both palp with bulb not in original position): Patella with central, wide patellar process; palpal tibia short, tibial process bi- furcate; cymbium distally rounded (Fig. 9E). Bulb oval; embolus long and sinuous (Fig. 9F).

Distribution. Argentina; Uschuaia, Chile; Puerto Toro and Puerto Pantalon.

Current systematic position. Hahniidae, Intihuatana antarctica (Simon, 1902). 

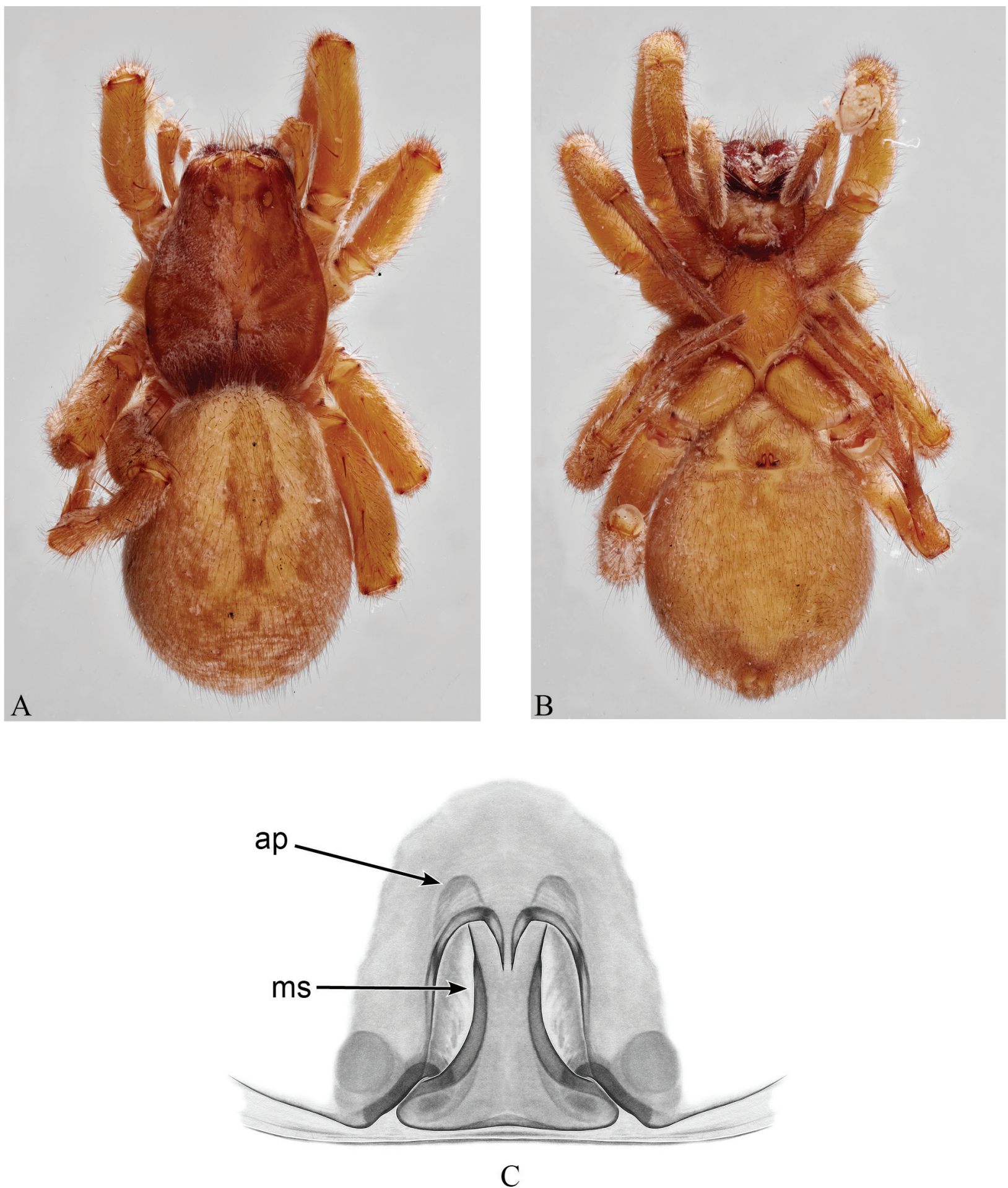

Figure 10. Lycosa michaelseni Simon, 1902. Female. A. Habitus, dorsal view. B. Habitus, ventral view. C. Epigynum, ventral view. Abbreviations: ap: anterior pocket, ms: median septum.

\section{Family Lycosidae}

\section{Lycosa michaelseni Simon, 1902}

Fig. 10A-C

Lycosa michaelseni Simon, 1902: 42 (Lycosa Michaelseni n. sp. description female).

Alopecosa michaelseni Mello-Leitão, 1947: 263 (trans- ferred to Alopecosa).

Alopecosa michaelseni Casanueva, 1980: 54 (nomina dubia).

Type locality. Coll. Mich. 85. Süd-Patagonien, Punta Arenas, Wald; 18. X. 92. Coll. Mich. 179. Süd-Feuerländ. Archipel, Isl. Navarin, Puerto Toro, Wald; XI. 92 (F. Delfin leg.).

Dimensions. + . long. $10 \mathrm{~mm}$. 
Determination label. Lycosa Michaelseni n. sp. Nr. 68. Locality label. 85. [Mag. Hb]. Punta Arenas, Wald. Coll. Michaelsen. 18. X. 92.

Type material. Lectotype $\uparrow$ designated here (ZMH-A0000766).

Remarks. Lycosa michaelseni was transferred by Mello-Leitão (1947: 263) to Alopecosa, and than declared a nomen dubium by Casanueva (1980: 54); "La descripción original dada por Simon define caracteres que en su mayor parte coinciden con las de otras especies del género Lycosa. La falta de material tipo (probablemente perdido) no permite reconocer a esta especie". The other specimen mentioned by Simon from Puerto Toro was not found in the $\mathrm{ZMH}$ collection.

Description. Female (lectotype). Total length: 10.97; cephalothorax length: 4.73; cephalothorax width: 3.48. COLORATION: (from original description, translated from Latin): "cephalothorax with black forehead, covered by yellow-grayish hairs, with a submarginal sinuous line on both sides. Abdomen black with dark brown hair, intermingled with a few white hairs, longitudinal lanceolate concolor band, posteriorly with spots in two rows, scarcely marked".

CEPHALOTHORAX: Longer than wide, not elevated (Fig. 10A). Chelicerae with two promarginal and two retromarginal teeth. EYES: AME larger than ALE, AER straight in anterior view. ABDOMEN: Oval (Fig.10A). LEGS: Tibia I with three pairs of ventral spines (2-2-2). GENITALIA: Short, inverted T-shaped median septum; anterior pockets shallow (Fig. 10B, C).

Male. Unknown.

Distribution. Chile: Punta Arenas.

Note. Aleopcosa is a large genus of wolf spiders with currently 161 desribed species that are distributed in Eurasia ( $75 \%$ of species), and a few (9\%) with a Holarctic or Palearctic distribution (Blagoev \& Dondale 2014). Only seven species occur in South America (Venezuela, Ecuador and Argentina) and probably do not belong to that genus but we retain this species in Alopectosa, emphasizing the need for revision.

Current systematic position. Lycosidae, Alopecosa michaelseni (Simon, 1902).

\section{Discussion}

\section{Into darkness - the "loss" of types}

Labelling and curatorial order of the ZMH specimens collected by Michaelsen is surprisingly straight forward and it is quite surprising that some of the type material was considered lost for a long time. All ZMH specimens have a determination label with a species number that corresponds to the numbering system that is used in the original manuscript by Simon (Fig. 1B) plus a locality label (either printed or handwritten) with a collection number linked to Michaelsen collection notes (Fig. 1C). The data derived from the jars and labels always match the original publication and only a few mistakes have been found (noted in the Remarks sections). One aspect that may have added to the confusion is that Simon described species from two different sources and one is from the material collected by Michaelsen and clearly labelled as such (e.g.: Coll. Mich. 3. Chile, Quipué. 11.VI. 93), whereas the other is from an unknown collection (only the locality is given, but not the collector, nor the collection, e.g. Fundort: Chile). Perhaps the unknown second source has confused subsequent authors but this is not certain. What is certain is that Simon's habit of not designating types, nor mentioning the number of specimens he examined as part of the descriptive process, as well as the possibility that Simon filled type series subsequently with non-type material (Peter Jäger pers. comm) has contributed to their neglect by subsequent taxonomists from all over the world. Further impediments to their recognition are the extremely stenographic descriptions that also lack any illustrations. The taxonomic "kill" finally occurred when Simon split the material collected by Michaelsen and retained some of the specimens in Paris, so that taxonomists were searching for them at the MNHN, but not in Hamburg. The multiplication of all these factors have probably sunk these types into oblivion.

\section{Raising the dead}

Of the 29 spider species described by Simon in his 1902 paper, some subsequent authors correctly assigned the types and mentioned that the specimens were deposited in the Hamburg Museum (Gerschman and Schiapelli 1968, Platnick and Shadab 1983, Millidge 1985 and Álvarez-Padilla 2007), whereas others did not consider the specimens of the Hamburg Museum, either because they were not aware of their existence, or they simply considered them lost (e.g. Exline 1960, Roth 1967, Casanueva 1980, Ramírez 2003 and Miller 2007). This has created some taxonomic imbroglio and erroneous nomina dubia that were re-evaluated as part of this study. For example, Casanueva (1980), Ramírez (2003), and Miller (2007) were not aware that the species described by Simon may have been part of a series and that the types or syntypes were held in the ZMH. As such, Miller designated the species he could not find in Paris as a nomen dubium and those that he found (probably syntypes) he declared as holotypes. In the same instance, Ramírez also used the specimens from Paris and mentions seeing "holotypes", because he was not aware of the ZMH specimens. We emphasize once more that the specimens in Paris are most likely syntypes, but also state that this is merely an interpretation, because Simon may have had other specimens from the same locality from other collectors.

\section{Open questions}

In the case of Tomopisthes, we refrained from designating lectotypes since Ramírez (pers. comm.) commented that Tomopisthes is under taxonomic revision and that there are numerous, closely related species, that could be under the same species name. Two species described by 
Simon (1902) remain a mystery: a vial labelled as Bathyphantes lennoxensis in the ZMH collection with the right locality and collecting data that includes an adult Lycosidae. It is very unlikely that Simon confused a linyphiid with a lycosid, hence we assume that a mistake was made when transferring the specimen to the vial. The second mystery species, Bathyphantes fissidens was also found in the ZMH collection with the right information. Simon gave a detailed description of the male palp, but only a juvenile female was found in the ZMH collection. Simon did not mention how many specimens he had for his description, therefore it is possible that syntypes are to be found at the Paris Museum.

\section{Conclusions}

The current study showcases - once more - the difficulties in working with very old type collections. Whilst the documentation of old and pale types that are locked away in large collections seems little adventurous, it provides the foundation for any work to come and taxonomic chaos and redundancy results if that study is not being done. We all have to face the problem of revising and looking for types all over the world and often consider this as wasted time but documenting, redescribing and illustrating types is of significant importance to ensure taxonomic stability, as well as offering valuable historical, biological and biogeographical data.

\section{Acknowledgements}

We sincerely thank Martina Mistera (CeNak) for helping us to find the picture of Wilhelm Michaelsen and Dr. Martin Ramírez for commenting on the taxonomic status of Tomopisthes. We also thank the referees for constructive criticism on an earlier draft of this manuscript. This study was made possible in part through the help of the "Society of the friends and donors of the Zoological Museum in Hamburg" who kindly provided financial support for a partial inventory of the ZMH collections.

\section{References}

Agnarsson I (2004) Morphological phylogeny of cobweb spiders and their relatives (Araneae, Araneoidea, Theridiidae). Zoological Journal of the Linnean Society 141: 447-626. https://doi.org/10.1111/ j.1096-3642.2004.00120.x

Álvarez-Padilla F (2007) Systematics of the spider genus Metabus O. P.-Cambridge, 1899 (Araneoidea: Tetragnathidae) with additions to the tetragnathid fauna of Chile and comments on the phylogeny of Tetragnathidae. Zoological Journal of the Linnean Society 151: 285-335. https://doi.org/10.1111/j.1096-3642.2007.00304.x

Birabén M (1957) Sobre Bigois antarctica Simon y descripcion del allotypus (Araneae Hahniidae). Revista Chilena de Entomología 5: 3-8.
Blagoev GA, Dondale CD (2014) A new species of Alopecosa (Araneae: Lycosidae) from Canada: a morphological description supported by DNA barcoding of 19 congeners. Zootaxa 3894(1): 152-160. https://doi.org/10.11646/zootaxa.3894.1.12

Blackwall J (1859) Descriptions of newly discovered spiders captured by James Yate Johnson Esq., in the island of Madeira. Annals and Magazine of Natural History (3)4: 255-267. https://doi. org/10.1080/00222935908697122

Casanueva ME (1980) Los licosidos de Chile. Estudio biologico y taxonomico por los metodos de sistematica alfa y taxonomica numerica (Araneae: Lycosidae). Gayana (Zool.) 42: 1-76

Denis J (1949) Notes sur les érigonides. XVI. Essai sur la détermination des femelles d'érigonides. Bulletin de la Société d'Histoire Naturelle de Toulouse 83: 129-158.

Exline H (1960) Rhoicinine spiders (Pisauridae) of western South America. Proceedings of the California Academy of Sciences 29: 577-620.

Gerschman de P. BS, Schiapelli RD (1968) El género Tryssothele Simon, 1902 (Araneae, Dipluridae). Physis, Revista de la Sociedad Argentina de Ciencias Naturales (C)28: 21-31.

Harms D, Dupérré N (2018) An annotated type catalogue of the camel spiders (Arachnida: Solifugae) held at the Zoolgical Musuem in Hamburg. Zootaxa 4375(1): 001-058. https://doi.org/10.11646/zootaxa.4375.1.1

ICZN (2017) International Comission on Zoological Nomenclature. International code of Zoological nomenclature. http://www.iczn.org/ [accessed 22 December 2017]

Lehtinen PT (1967) Classification of the cribellate spiders and some allied families, with notes on the evolution of the suborder Araneomorpha. Annales Zoologici Fennici 4: 199-468.

Levi HW (1962) The spider genera Steatoda and Enoplognatha in America (Araneae, Theridiidae). Psyche, Cambridge, 69: 11-36. https://doi.org/10.1155/1962/42957

Levi HW (1963) The American spiders of the genus Anelosimus (Araneae, Theridiidae). Transactions of the American Microscopical Society 82: 30-48. https://doi.org/10.2307/3223818

Levi HW (1967) The theridiid spider fauna of Chile. Bulletin of the Museum of Comparative Zoology at Harvard College 136: 1-20.

Mello-Leitão CF de (1947) Aranhas do Paraná e Santa Catarina, das coleções do Museu Paranaense. Arquivos do Museu Paranaense 6: 231-304.

Michaelsen W (1896) Reisebericht. Ergebnisse der Hamburger Magalhaensische Sammelreise 1892/1893. Published by the Naturhistorischen Museum zu Hamburg. I. Band. Allgemeines, Chordatiere, Echinodermen und Coelenteraten. Hamburg L Friederichsen \& Co. 1896-1907, 1-47.

Miller JA (2007) Review of erigonine spider genera in the Neotropics (Araneae: Linyphiidae, Erigoninae). Zoological Journal of the Linnean Society 149(Suppl. 1): 1-263.

Millidge AF (1985) Some linyphiid spiders from South America (Araneae, Linyphiidae). American Museum Novitates 2836: 1-78.

Neumayer Gv (1896) Vortwort. Ergebnisse der Hamburger Magalhaensischen Sammelreise 1892/1893. Published by the Naturhistorischen Museum zu Hamburg. I. Band. Allgemeines, Chordonire, Echinodermen und Coelenteraten. Hamburg L Friederichsen \& Co. 1896-1907, I-IV.

Nicolet H (1849) Aracnidos. In: Gay C (Ed.) Historia física y política de Chile. Zoología 3: 319-543. [pl. 1-5]

Petrunkevitch A (1911) A synonymic index-catalogue of spiders of North, Central and South America with all adjacent islands, Green- 
land, Bermuda, West Indies, Terra del Fuego, Galapagos, etc. Bulletin of the American Museum of Natural History 29: 1-791.

Pickard-Cambridge FO (1899) On some spiders from Chili and Peru collected by Dr. Plate of Berlin. Journal of the Linnean Society of London, Zoology 27: 15-22, P1. 2.

Platnick NI, Shadab MU (1983) A revision of the Neotropical spider genus Apodrassodes (Araneae, Gnaphosidae). American Museum Novitates 2763: 1-14.

Roth VD (1967) A review of the South American spiders of the family Agelenidae (Arachnida, Araneae). Bulletin of the American Museum of Natural History 134: 297-346.

Schiapelli RD, Gerschman de PBS (1959) Aclaración sobre los caracteres genéricos del género Bigois Simon, 1898 (Araneae, Hahniidae). Revista de la Sociedad Entomológica Argentina 21: 129-132 .

Schiapelli RD, Gerschman de PBS (1974) Arañas de las islas Malvinas. Revista del Museo Argentino de Ciencias Naturales Bernardino Rivadavia (Ent.) 4: 79-93.

Simon E (1882) Études Arachnologiques. 13e Mémoire. XX. Descriptions d'espèces et de genres nouveaux de la famille des Dysderidae. Annales de la Société Entomologique de France (6)2: 201-240.

Simon E (1884) Les arachnides de France. Paris 5, 180-885.

Simon E (1886) Arachnides recueillis en 1882-1883 dans la Patagonie méridionale, de Santa Cruz à Punta Arena, par M. E. Lebrun, attaché comme naturaliste à la Mission du passage de Vénus. Bulletin de la Société Zoologique de France 11: 558-577.

Simon E (1887) Arachnides. Mission scientifique du Cap Horn, 18821883. Paris 6, E1-E42.

Simon E (1889) Études arachnologiques. 21e Mémoire. XXX. Descriptions de quelques arachnides du Chili et remarques synonymiques sur quelques unes des espèces décrites par Nicolet. Annales de la Société Entomologique de France (6)8: 217-222.

Simon E (1895) Arachnides recueillis a la Terre-de-feu par M. Carlos Backhausen. Anales del Museo Nacional de Buenos Aires 4 (ser. 2, t. 1): 167-172.

Simon E (1896) Arachnides recueillis à la Terre-de-feu par M. Carlos Backhausen. (2e Mémoire). Anales del Museo Nacional de Buenos Aires 5(ser. 2, t. 2): 141-145.

Simon E (1902) Arachnoideen, excl. Acariden und Gonyleptiden. Ergebnisse der Hamburger Magalhaensischen Sammelreise 1892/1893. Published by the Naturhistorischen Museum zu Hamburg II. Band. Arthropoden. Hamburg L Friederichsen \& Co. 1896-1907. 1-47.

Tullgren A (1901) Contribution to the knowledge of the spider fauna of the Magellan Territories. Svenska Expeditionen till Magellansländerna. 2(10): 181-263.

Vellard J (1958) Études fuégiennes. Travaux de l'Institut Français d'Études Andines 6: 119-145.

World Spider Catalogue (2018) Version 18.5. Natural History Museum Bern. http://www.wsc.nmbe.ch/ [accessed 22 January 2018] 